\title{
ZYGMUNT ZAWIRSKI WŚRÓD INŻYNIERÓW I ORGANIZATORÓW - CZĘŚĆ 1
}

DOI: $10.33141 /$ po. 2020.12.05

Alojzy Czech
Przegląd Organizacji, Nr 12(971), 2020, s. 37-43

www.przegladorganizacji.pl

๑) Towarzystwo Naukowe Organizacji i Kierownictwa (TNOiK)

\section{Wprowadzenie}

$\mathbf{P}$ owstająca w początkach XX wieku nauka o organizacji i zarządzaniu miała korzenie sięgające różnych dziedzin, jak również przyciągała uczonych i twórców najróżniejszych profesji. Takim zupełnie do dziś nieznanym związkiem $\mathrm{z}$ dziedziną zarządzania jest krótkotrwała obecność wśród organizatorów Zygmunta Zawirskiego, logika i filozofa, wybitnego reprezentanta cenionej w świecie filozoficznej szkoły lwowsko-warszawskiej w jej pierwszym pokoleniu. Wespół z Kazimierzem Twardowskim, Kazimierzem Ajdukiewiczem, Tadeuszem Czeżowskim, Tadeuszem Kotarbińskim, Stanisławem Leśniewskim, Janem Łukasiewiczem i Alfredem Tarskim tworzył „korpus typowych dla tej szkoły poglądów" (Zamecki, 1977, s. 56 i 175; Woleński, 1985, s. 25). Warto przypomnieć ten związek, gdyż dotąd był zupełnie pomijany. Tymczasem poprzez kontakt $\mathrm{z}$ nową doświadczalną problematyką psychologiczną oraz pobyt w środowisku politechnicznym Zawirski zajął się praktycznym zastosowaniem psychologii $\mathrm{w}$ przemyśle, kierując nawet tworzoną wtedy pracownią psychotechniczną. Z tego też powodu znalazł się pośród uczestników II Zjazdu Polskiego Naukowej Organizacji, występując jako rzecznik i sprawozdawca tych aplikacji. W opracowaniach omawiających dokonania Zawirskiego związki z psychotechniką nie były w ogóle podnoszone. Co najwyżej wskazuje się na jego dydaktyczną kooperację z Politechniką Lwowską (Gawecki, 1948, s. 436; Ingarden, 1948, s. 7; Galeński, 1948, s. 81; Jadacki, 1998, s. 202; Hajduk, 2001, s. 865). Wydany w 1992 roku Stownik psychologów polskich Zawirskiego w tym gronie nie umieszcza wcale. Opracowana przez Irenę Szumilewicz-Lachman w serii Boston Studies In the Philosophy of Science monografia $\mathrm{w}$ wykazie prac Zawirskiego wymienia trzy dokonania z zakresu psychologii (Szumilewicz-Lachman, 1994, s. 376)1, nie rozwijając tego aspektu. Ryszard Jadczak (1993, s. 201) jedynie wspomniał o kierowaniu przez Zawirskiego pracownią psychotechniczną.

Tymczasem bardzo fortunnie się stało, że w okresie kształtowania się nauk o zarządzaniu w Polsce autor o tak wyrafinowanym znawstwie problematyki naukowej, w szczególności przyrodoznawstwa, swoim potencjałem wsparł tworzące się środowiska i instytucje w nowej dziedzinie wiedzy stosowanej, jakim stawało się zarządzanie. Nic dziwnego także, że związki Zawirskiego $\mathrm{z}$ naukową organizacją dotyczyły człowieka w miejscu pracy i jego predyspozycji zawodowych, a nie zarządzania całymi organizacjami. W latach 20 . XX wieku badania nad psychofizjologicznymi uwarunkowaniami pracowników stanowiły przecież jeden z głównych nurtów organizatorskich w ramach ówczesnych kierunków, tak scientific management, jak i tworzącego się human relations, a psychotechnika uważana była za stowarzyszoną z naukową organizacją gałęzią psychologii. Zawirski dał temu dwukrotnie wyraz w swoich mało znanych artykułach zamieszczanych na łamach „Czasopisma Technicznego” oraz „Przeglądu Organizacji”. Stanowią one główny punkt źródłowego odniesienia. Biografia została uzupełniona o źródła archiwalne. Odtwarzając poniżej zawartość pierwszego z opracowań, dokonano dodatkowo kontekstowego osadzenia występujących $\mathrm{w}$ oryginale nazwisk uczonych, ich dzieł oraz głównych stanowisk $\mathrm{w}$ tamtejszych realiach, tak naukowych, jak i instytucjonalnych. Filozoficzno-logiczny dorobek Zawirskiego, poprzez omówienie jego uwag na temat psychotechniki, został o ten pomijany fragment uzupełniony. Także lwowski ośrodek organizatorski, co prawda na krótki okres, poprzez zaangażowanie Zawirskiego doznał poważnego naukowego wzmocnienia. Warto o tym dopowiedzieć, tym bardziej, że przy okazji niektóre prace Zawirskiego, o nieprzemijającym znaczeniu dla uprawiania nauki w ogóle, jak monografia o czasie czy studia o metodzie w naukach empirycznych, zostały wybiórczo dla środowiska organizatorskiego przypomniane i rekomendowane.

\section{Wykształcenie, wczesna twórczość}

$\mathbf{Z}$ ygmunt Michał Zawirski urodził się 28 lipca 1882 roku w Berezowicy Małej, woj. tarnopolskie, w rodzinie lekarskiej, posiadającej liczne potomstwo. Ukończył III Gimnazjum we Lwowie (Archiwum UJ, sygn. S/II/619), w latach 1901-1906 studiował filozofię pod kierunkiem Kazimierza Twardowskiego na Wydziale Filozoficznym Uniwersytetu Jana Kazimierza. Pod jego kierunkiem w 1907 roku obronił pracę doktorską na temat modalności sądów logicznych (Archiwum UAM, sygn. 152/32; Jadczak, 1993, s. 197), opublikowaną kilka lat później pod tytułem $O$ modalności sąów (Wydawnictwo Polskiego Towarzystwa Filozoficznego, Lwów 1914). 
Po studiach rozpoczął ponad dwadzieścia lat trwającą gimnazjalną pracę nauczycielską. Początkowo jako zastępca nauczyciela w C.K. IV Gimnazjum we Lwowie, by po uzyskaniu w 1907 roku stosownych uprawnień z propedeutyki filozofii i matematyki jako przedmiotów głównych i fizyki jako przedmiotu pobocznego, kontynuować działalność pedagogiczną jako nauczyciel w Gimnazjum w Rzeszowie w latach 1907-1911. Wtedy też wydał fragment opracowania z zakresu psychologii, które powstało jeszcze podczas studiów na seminarium $\mathrm{u}$ prof. Twardowskiego Ilość praw kojarzenia przedstawień. Szkic historyczno-psychologiczny (Sprawozdanie Dyrekcji C.K. II Gimnazjum w Rzeszowie za rok szkolny 1909, Rzeszów 1909), w którym wysunął projekt redukcji praw kojarzenia do jednego - według zasady styczności (Jadacki, 1998, s. 204). Nawiasem mówiąc, w tym samym czasie Twardowski doprowadził do utworzenia w 1907 roku pracowni psychologicznej, która stała się integralną częścią Uniwersytetu (Rzepa, Dobraczyński, 2009, s. 164), ale Zawirski z nową placówką nie miał kontaktów. Praktyką natomiast było, że wychowankowie Twardowskiego, pracujący jako nauczyciele gimnazjalni, utrzymywali kontakt naukowy z mistrzem, który popierał podtrzymywanie częstych wśród nich postaw badawczych. Tak też było w przypadku Zawirskiego.

W roku 1909 wnioskował o urlopowanie z pracy nauczycielskiej, gdyż wystąpił o stypendium na dokształcanie. Otrzymał zasiłek rządowy dzięki poparciu otrzymanemu ze strony Senatu UJK na wniosek prof. Twardowskiego. Procedura się przedłużała i dopiero z początkiem 1910 roku mógł wyjechać do Berlina, słuchając na tamtejszym Uniwersytecie wykładów neokantysty Aloisa Riehla (1844-1924), socjologa Georga Simmla (1858-1918) oraz psychologa Carla Stumpfa (1848-1936), z których - jak informował w liście swego mistrza prof. Twarowskiego - najwięcej korzystał (Jadczak, 1993, s. 199). Uczęszczał też na ćwiczenia z psychologii doświadczalnej w pracowni tego ostatniego. Zapoznał się również $\mathrm{z}$ eksperymentami prowadzonymi w Instytucie Psychologicznym, co było dla niego nowością. W semestrze letnim przebywał na Sorbonie i w College de France w Paryżu, wybierając wykłady psychologów Pierre Janeta (1859-1947), Georgesa Dumasa (1866-1946) i innych (Archiwum UAM, sygn. 152/32). $\mathrm{Z}$ pewnością te doświadczenia legły u podstaw jego przyszłych prac i działań w zakresie psychologii stosowanej. Wzmocniony rozeznaniem $\mathrm{w}$ kierunkach badań obecnych $\mathrm{w}$ filozofii europejskiej dawał temu wyraz w powstałych po powrocie pracach naukowych. Przejawem tego jest zwłaszcza rozprawa Przyczynowość a stosunek funkcjonalny. Studia z zakresu teorii poznania („Przegląd Filozoficzny” r. XV, 1912, także nadbitka Warszawa 1912), wyróżniona pierwszą nagrodą w trzecim konkursie tego warszawskiego periodyku.

Po powrocie z podróży studyjnej podjął pracę w III Gimnazjum we Lwowie, ale już na przełomie lat 1914/1915 opuścił miasto $\mathrm{z}$ powodu zagrożenia wojennego, przenosząc się do Grazu, gdzie na tamtejszym Uniwersytecie kontynuował badawcze dociekania. Od 1915 roku do końca pobytu we Lwowie w 1928 roku powrócił do nauczania w VII Gimnazjum Lwowskim, prowadząc równolegle $\mathrm{z}$ dydaktyką intensywną pracę naukową. $\mathrm{Z}$ tego okresu zapamiętał go wtedy uczeń gimnazjalny Józef M. Bocheński (1902-1995), kreśląc sylwetkę nauczyciela matematyki zatopionego $\mathrm{w}$ problemach zalegających jego umysł: „Zawirski uchodził u nas za mistyka, bo łatwo go było wprowadzić w kontemplacyjne myślenie" (Bocheński, 1993, s. 36). Działo się tak podczas toku zajęć. Mimo uczniowskich żartów, jakie sobie strojono, nie wpłynęło to na relacje pomiędzy różniącymi się przecież wiekiem osobami. Zawirski chwalił swego ucznia na maturze, dając mu do rozwiązania trudne zadania wykraczające poza program nauczania, zaś przyszły wybitny przedstawiciel filozofii analitycznej uważał gimnazjalnego nauczyciela za swego pierwszego mistrza.

Lwów w latach przed wielką wojną oferował różne możliwości naukowego zaistnienia także dla osób spoza uniwersytetu. Od 1911 roku ukazywał się z inicjatywy Kazimierza Twardowskiego „Ruch Filozoficzny” jako organ Polskiego Towarzystwa Filozoficznego (PTF), dla którego Zawirski sporządzał przeglądy zagranicznych czasopism i wydawnictw, głównie francuskich. Regularnie uczestniczył też w posiedzeniach PTF, wygłaszając na jego forum szereg odczytów, rozwijanych w następnych latach w znaczące rozprawy, co nasiliło się zwłaszcza po odzyskaniu niepodległości. Z rekomendacji prof. Twardowskiego dokonał przekładu podręcznika Alojzego Hoeflera (1853-1922) Zasady psychologii (Księgarnia Naukowa Lwów-Warszawa 1922; 2. wyd. 1927), także tegoż autora Logika propedeutyczna (nakładem Księgarni Naukowej, Lwów 1927), podręcznik dla szkół średnich. W 1922 roku został wykładowcą Politechniki Lwowskiej.

W 1921 roku utworzony został wzorem rozwiązań obecnych na politechnikach austriackich Wydział Ogólny $\mathrm{z}$ zadaniem kształcenia głównie nauczycieli przedmiotów przyrodniczych i matematyki w szkołach zawodowych i średnich technicznych (Politechnika Lwowska, 1932, s. 258). Nie miał on struktury katedralnej, jak dotąd istniejące Wydziały, korzystał jednak z ich zasobów kadrowych, jak też osób pozyskanych z zewnątrz. Jednym z wykładowców został właśnie Zawirski, który otrzymał zlecenie na zajęcia $\mathrm{z}$ filozofii. $\mathrm{Z}$ biegiem czasu - do 1928 roku - doszły jeszcze logika, logika matematyczna, teoria dedukcji Russella, teoria stosunków, logiczne podstawy matematyki i przyrodoznawstwa oraz psychologia (Archiwum UAM, sygn. 152/32). Jak widać, był to wachlarz zagadnień/przedmiotów charakterystycznych dla analitycznej szkoły lwowsko-warszawskiej. Przy podstawowym zatrudnieniu w gimnazjum - rysuje się obraz Zawirskiego bardzo obciążonego obowiązkami dydaktycznymi. W tych tak trudnych dla siebie warunkach potrafił przejść kolejną próbę naukową w postaci habilitacji.

W styczniu 1924 roku sfinalizowany został przewód Zawirskiego na Wydziale Filozoficznym Uniwersytetu Jagiellońskiego. Przygotowaniem były poprzedzające habilitację, a będące następstwem odczytów we lwowskim PTF publikacje artykułowe: Refleksje filozoficzne nad 
teorią względności („Księga Pamiątkowa ku czci Prof. Twardowskiego”, wydanie specjalne „Przeglądu Filozoficznego", 1921) oraz Relatywizm filozoficzny a fizykalna teoria względności (nakładem własnym, Lwów 1921). Uczyniły z Zawirskiego jednego z najlepszych znawców filozoficznych konsekwencji najnowszych teorii fizykalnych. Podstawą wszczęcia przewodu habilitacyjnego była rozprawa Metoda aksjomatyczna a przyrodoznawstwo („Kwartalnik Filozoficzny”, r. 1, nadbitka, Kraków 1923). Opiekę nad przewodem przyjął prof. Władysław Heinrich (1869-1957), uczeń Avenariusa, zwolennik filozofii zorientowanej na problem psychofizyczny, psycholog doświadczalny, z którym Zawirski pozostanie w bliskich relacjach naukowych. Wykład habilitacyjny dotyczył Związku zasady przyczynowości z zasada względności („Kwartalnik Filozoficzny”, t. II, Kraków 1924). W 1925 roku veniam legendi zostało uznane przez Politechnikę Lwowską i wymienione wyżej zajęcia prowadził już jako samodzielny pracownik nauki, co z pewnością dawało większą swobodę doboru i kształtowania ich treści.

\section{Psychologia jako nauka empiryczna}

W dniu 11 lutego 1925 roku Zygmunt Zawirski miał na forum Towarzystwa Politechnicznego we Lwowie odczyt, który niebawem został na łamach "Czasopisma Technicznego" opublikowany pod tytułem Podstawy psychotechniki i jej rozwój. Był to dwugłos. Tuż po Zawirskim obszerny koreferat zamieścił prof. inż. Edward T. Geisler (1884-1966), kierownik Katedry Obróbki Metali na Wydziale Mechanicznym Politechniki Lwowskiej (Barylski, 2013, s. 51), który przedstawił spojrzenie inżynierskie na zagadnienie predyspozycji człowieka w procesach wytwórczych. Także jego wystąpienie zatytułowane Psychotechnika, jej cele i drogi znalazło się w tym numerze „Czasopisma Technicznego”, który zresztą przez redakcję nazwany został zeszytem psychotechnicznym. Znany z zasług dla naukowego zarządzania prof. Geisler swój referat powtarzał jeszcze $\mathrm{w}$ innych kręgach, w tym na forum lwowskiego Instytutu Technologicznego, w ramach którego zamierzano utworzyć pracownię psychotechniczną. Wróćmy jednak do wykładu Zawirskiego, który dla słuchaczy i czytelników ze świata techniki w swym wystąpieniu osadzał rodowód tej praktycznej wiedzy w nauce teoretycznej.

Rozpoczął - jako filozof nauki - od zachodzącej analogii pomiędzy współczesną fizyką a psychologią doświadczalną. Ta druga przez stulecia była uprawiana pod szyldem dociekań o istocie duszy i pomimo braku jednoznacznej odpowiedzi w tej kwestii, dzięki oparciu badania życia psychicznego/duchowego na obserwacji i eksperymencie, przyniosła szereg rezultatów znacząco wzbogacających sprawdzalną wiedzę o człowieku. Podobnie w fizyce, dzięki postępom badawczym i obliczeniowym, wysunięto i uzasadniano liczne nowe inspirujące teorie, pozostawiając właściwie metafizycznym filozofom refleksję nad pojęciem materii. Brak rozstrzygającej odpowiedzi, czy to $\mathrm{w}$ kwestii duszy czy materii, nie był przeszkodą w odkrywaniu „coraz to nowych praw przyrody, które stosowane do zadań praktycznych, były podstawą do olbrzymiego rozwoju techniki, przeobrażającej całą kulturę, a współczesna psychologia w oparciu o metodę empiryczną potrafi obecnie sprostać pewnym oczekiwaniom, jakie wobec niej wysuwa życie i jego rosnące potrzeby" (Zawirski, 1926, s. 149).

W XIX-wiecznym narastaniu prób eksperymentalnych, posiadających znaczenie dla psychologii stosowanej, Zawirski wybiera i skupia się na kilku takich przypadkach. Przypomnienie rozpoczyna od wskazania na związek wrażeń i podniet je wywołujących. Nie jest to zależność stała, nie każdy bowiem przyrost bodźca jest od razu dostrzegalny w postaci wzrostu reakcji czuciowej. Tak w każdym razie wynika z obserwacji przeprowadzonej przez pracującego w Lipsku niemieckiego fizjologa Ernsta H. Webera (1795-1878), który wykazał, iż „zmiana czucia nie zależy od bezwzględnego przyrostu podniety, lecz od stosunku tegoż przyrostu do podniety całej" (Zawirski, 1926, s. 149)2. Stosunek ten jest dla każdego ze zmysłów stały, i tak dla dotyku wynosi $1 / 10$, dla wzroku przy ocenie długości od 1/50 do 1/100 itd. To prawo Webera było impulsem do badań Gustava Fechnera (1801-1887), filozofa problemu psychofizycznego, nad tzw. „formułką miary” głoszącą, iż „wrażenie równa się logarytmowi podniety” (Zawirski, 1926, s. 150). Zawirski akcentował znaczenie prac Fechnera nad psychofizycznymi metodami badania wrażeń zmysłowych wobec fizycznych podniet, oddziałujących także w obrębie psychotechniki. Badanie sprawności zmysłów jest bowiem ważne dla oceny przydatności poszczególnych jednostek do danych zawodów.

Kolejnym zagadnieniem, którego próby rozwiązania fundowały psychologię eksperymentalną, były badania nad pamięcią, zapoczątkowane przez wrocławskiego psychologa Hermanna Ebbinghausa (1850-1909). Były to badania wiwisekcyjne. Uczony ten, badając proces uczenia się szeregu wyrazów jednozgłoskowych, będących dowolną kombinacją liter, dążył do znalezienia odpowiedzi na kilka kwestii dotyczących pamięci, takich jak: 1. Na ile zależna jest szybkość wyuczenia się od długości szeregu? 2. Jaka jest zależność trwałości szeregów w pamięci od ilości powtórzeń? 3. Jaka jest zależność trwałości i dobroci pamiętania od czasu, jaki upływa pomiędzy wyuczeniem się a powtórzeniem szeregu? 4. Jak wygląda określenie stosunku zależności zapamiętania od ilości powtórzeń, dokonywanych przy kilkakrotnym uczeniu się tego samego szeregu w równych odstępach czasu? 5. Jak kształtuje się zależność pamiętania szeregu od porządku kolejności zgłosek w szeregu? Każda $\mathrm{z}$ tych pięciu grup eksperymentalnie badanych zależności doprowadziła do pewnych prawidłowości, które mogły być wykorzystane w praktycznym wymiarze. Najciekawsza była konkluzja zagadnienia trzeciego, którego wynik dał się ująć - podobnie jak to później będzie w taylorowskiej metodzie - w formułę matematyczną. „Uczenie się ponowne pewnego szeregu wyrazów po upływie jakiegoś czasu wykazuje 
zawsze pewne zaoszczędzenie czasu w stosunku do czasu pierwotnego. Otóż - relacjonował Zawirski za Ebbinghausem - stosunek czasu zaoszczędzonego do czasu na nowo przy uczeniu się użytego jest odwrotnie proporcjonalny do logarytmu z czasu, który upłynął między pierwotnym uczeniem się a ponownym powtórzeniem (Zawirski, 1926, s. 150):

$$
\frac{b}{v}=\frac{k}{(\log t)^{\mathrm{c}}}
$$

gdzie: $b$ - czas zaoszczędzony przy powtórnym nauczeniu, $v$ - czas potrzebny do nauczenia się przy powtarzaniu, $k$ - czas (zapomnienia), który upłynął pomiędzy pierwotnym uczeniem się a ponowieniem uczenia się.

Formuła ta poddana została w wątpliwość z punktu widzenia powszechnej ważności. Trudności sprawiało jej teoretyczne uzasadnienie. Ale nie bacząc na przeszkody w odkrywaniu praw życia psychicznego, badania były prowadzone. Doprowadzały do odkrywania różnic indywidualnych między ludźmi, mimo posiadania pewnych wspólnych dyspozycji psychicznych. W ten sposób powstała subdyscyplina zwana "psychologią różniczkową" (Zawirski, 1926, s. 150), zwana częściej psychologią różnic indywidualnych, biorąca za przedmiot badanie odmian zachodzących u poszczególnych jednostek w reagowaniu na zachodzące bodźce, w sposobie wyobrażania itp. Jednym z jej twórców był uczeń Ebbinghausa i jego następca na wrocławskim uniwersytecie William Stern (1871-1938), akcentujący praktyczne znaczenie powstającej subdyscypliny dla różnych działów psychologii stosowanej z psychotechniką włącznie.

Metodą szczególnie rozpowszechnioną $\mathrm{w}$ badaniu tak ogólnych prawidłowości przebiegu spraw psychicznych, jak też różnic indywidualnych była metoda testów. Polegała ona na zadawaniu badanym jednostkom określonych pytań do odpowiedzi lub czynności do wykonania, które nazwano testami. Nie były wymagane żadne specjalne przyrządy czy skomplikowane urządzenia, może z wyjątkiem prostych tablic. Dostrzegało się zaś badanie całej gamy zdolności i funkcji psychicznych, jak skupiania uwagi, zmysłu obserwacyjnego, pamięci, wyobraźni, ogólnego poziomu inteligencji. W dalszym ciągu prelegent demonstrował wybrane przypadki testów badających zdolność skupiania uwagi, a także jej podzielności, wyobraźni twórczej oraz domyślności jako cechy myślenia w ogóle (Zawirski, 1926, s. 150-151). Przyrządem obecnym w psychologii doświadczalnej, którego omówieniu Zawirski poświęcił więcej uwagi, był tachistoskop, aparat pozwalający badać naturę spostrzeżeń wzrokowych i mierzenie ich szybkości.

Osobnym zagadnieniem o dużym znaczeniu praktycznym były ergografy - przyrządy służące do pomiarów znużenia czy wytrzymałości w pracy. Ich stosowanie było dziełem fizjologa włoskiego Angelo Mosso (1846-1910). Wynik otrzymywało się w postaci krzywych znużenia. W miarę narastania znużenia krzywe te stawały się coraz krótsze. Co więcej - każdy badany osobnik posiadał charakterystyczną dla siebie krzywą. Jakkolwiek generalnie wyróżnione zostały dwa zasadniczo różne typy znużenia: $\mathrm{u}$ jednych występowało zaraz po rozpoczęciu pracy oraz narastało powoli i stopniowo, $\mathrm{u}$ innych nie dało się go stwierdzić w ciągu dłuższego czasu, występowało dopiero po pewnym okresie ostro i praca ustawała prawie nagle. Ergograf przeznaczony był do badania znużenia fizycznego, ale zostało potwierdzone wielokrotnie, iż zmęczenie fizyczne i umysłowe rozwijają się równolegle i są od siebie zależne. Zawirski sygnalizował też, iż do podobnych celów w tego typu badaniach użyty bywa zwykły dynamometr, a także cyrkiel zwany od nazwiska wymienionego już psychofizjologa Webera. Przyrząd ten pozwalał określać spadające reakcje na dotknięcie/ukłucie pod wpływem zmęczenia umysłowego. Nie omieszkał też wspomnieć, iż nauczyciel fizyki i matematyki w przemyskich i lwowskich gimnazjach prof. Bolesław Błażek (1872-1943?) z pomocą tej metody badał, jak rozwija się zmęczenie ucznia po określonych lekcjach i jakie w następstwie powinny być przerwy między lekcjami, by to zmęczenie kompensować3.

\section{Psychotechnika - jedno z zastosowań psychologii doświadczalnej}

W dokonanym przeglądzie osiągnięć i wskazań psychologii opartej na obserwacji i eksperymencie wspartych konstruowanymi przyrządami Zawirski wykazywał ich doniosłość dla potrzeb życia praktycznego. Widział następujące kierunki aplikacyjne: stosowanie ustaleń psychologii doświadczalnej do pracy wychowawczej i nauczycielskiej (wszak sam był nauczycielem); do leczenia pacjentów, czyli wzmacnianie psychiatrii (nie używał zwrotu psychologia kliniczna); w kryminalistyce i w ogóle w sądownictwie oraz w życiu gospodarczym. Ta ostatnia sfera praktyki zwana była psychotechniką, czyli „badaniem uzdolnień kandydatów do pewnych zawodów, celem postawienia właściwych ludzi na właściwym miejscu” (Zawirski, 1926, s. 151). Było to określenie Hugo Münsterberga (1863-1916), którego $\mathrm{w}$ zgodzie $\mathrm{z}$ powszechnie przyjętym ujęciem Zawirski uważał za twórcę tej praktycznej gałęzi wiedzy, a publikację Psychologie und Wirtschaftsleben (Verlag J.A. Barth, Leipzig 1912) ${ }^{4}$, wydanie angielskie Psychology and Industrial Efficiency (Houghton Mifflin Co., Boston 1913) za pierwszą poważną publikację w tym kierunku. Przywoływał autorskie badania Münsterberga przeprowadzone na motorniczych tramwajów elektrycznych, także kandydatów na oficerów okrętowych oraz telefonistek, których celem było, zwłaszcza w przypadku motorniczych, zapobieżenie wypadkom. Za kluczowe uznano zdolność ujmowania całości obrazu ulicy i umiejętność przewidywania wszelakich ruchów, jakie mogą nastąpić. W przypadku oficerów okrętowych decydujące było opanowanie z chwilą pojawienia się szybko występującej kombinacji czynników, wobec których trzeba reagować w sposób celowy. By przebadać kandydatów na te okoliczności, Münsterberg starał się wywiązać ze swego zadania $\mathrm{w}$ ten sposób, że „usiłował w pracowni swej odtworzyć sztucznie wszystkie te warunki, w jakich 
jednostka poświęcająca się pewnemu zawodowi znaleźć by się mogła i badał następnie, czy te jednostki potrafią w tych warunkach reagować celowo (Zawirski, 1926, s. 151). Jakiś czas trwało, zanim podobny impuls do takich praktyk pojawił się w Europie ${ }^{5}$.

Aplikację psychologii do potrzeb praktycznych w dużym stopniu przyśpieszały warunki wojenne. Rozpoczęto badania nad uzdolnieniem lotników, skupiając się na szybkości reakcji na podniety wzrokowe, słuchowe i dotykowe. Próbowano określić fizjologicznie uwarunkowanie przestrachu. W efekcie eliminowano osoby nieodpowiednie do tego zajęcia. Podobnie przeprowadzono szeroko zakrojone badania nad uzdolnieniem artylerzystów. Z chwilą przystąpienia Ameryki do wojny, $\mathrm{w}$ ten sam sposób przeprowadzany był nabór dwu milionów żołnierzy. Wyniki psychologiczne decydowały, czy umieszczano rekruta w szeregach kawalerii, artylerii bądź piechoty. Dużą wagę przykładano do testowania radiotelegrafistów. Badanie czynników psychicznych pojawiło się w fabrykach broni i amunicji. Zawirski powołał się na słynne badania robotnic identyfikujących poprzez dotyk wadliwe kulki stalowe w fabryce łożysk tocznych.

Ten ostatni jednakże przykład jest taylorowski. Badanie zostało przeprowadzone w Simonds Rolling Machine Co., Fitchburg, Ma. w latach 90. XIX wieku przez zespół Fr. Taylora (1856-1915) i miał na celu szukanie oszczędności podczas prowadzonej kontroli jakości kulek do łożysk rowerowych (Taylor, 1922, s. 49-55; Martyniak, 1993, s. 20-21). Zawirski miał tego świadomość. Miał świadomość, iż praca Taylora Principles of Scientific Management (Harper \& Bross, New York 1911) ${ }^{6}$ była wcześniejsza w stosunku do publikacji Münsterberga. Naukową organizację Zawirski widział jako „badanie środków, które wyłącznie zmierzają do tego, aby uczynić przedsiębiorstwo rentownym" (Zawirski, 1926, s. 152). W wydaniu taylorowskim pozostawała - wg Zawirskiego - na usługach kapitalistycznych tendencji wielkiego przemysłu, dlatego wśród mas robotniczych była bardzo niepopularna. Psychotechnika wolna była od tych zarzutów, przynosi bowiem korzyść tak przedsiębiorcy, jak i robotnikowi, gdyż potrafiła „wskazać ludziom właściwy dla nich kierunek zajęć” (Zawirski, 1926, s. 154).

Trudno się zgodzić $\mathrm{z}$ takim postawieniem sprawy. $\mathrm{W}$ relacji Taylora $\mathrm{z}$ przeprowadzonego eksperymentu usprawniającego - zgodnie z praktyką laboratoriów uniwersyteckich - wyraźnie położony był akcent na osobistej pobudliwości pracownic, która kształtowała się różnie nieraz w szerokich granicach. „Niektórzy posiadają wrodzone zdolności spostrzegania i wyjątkowo szybkiego reagowania myślowego. Wrażenie otrzymane przez nich przebiega niesłychanie szybko od oka do mózgu, a mózg odpowiada $z$ równą szybkością, wysyłając odpowiedni rozkaz do ręki; ludzie tego typu posiadają dużą pobudliwość osobistą. Odwrotnie, jednostki, których spostrzegawczość i reakcja myślowa są powolne, posiadają niewielką pobudliwość" (Taylor, 1922, s. 51). Trzeba wyjaśnić, iż sprawdzanie jakości odbywało się przez dostrzeżenie przez pracownice tam zatrudnione wad szeregu kulek umieszczonych w rowku między palcami lewej dłoni jej zewnętrznej części, wypatrzeniu plamek, prążków, nierówności, rys lub pęknięć i wyjęcie magnesem sztuk zdefektowanych. Wady te były ledwie widoczne lub niewidoczne; nic dziwnego, iż odkrycie ich wymagało wytężonej uwagi, zaś zatrudnione tu pracownice były znużone. Prowadzący ten eksperyment współpracownik Taylora Sanford E. Thompson (1867-1949) od razu zauważył, iż ów czynnik pobudliwości osobistej jest decydujący. Wskutek czego, po odpowiedniej selekcji, wydalił wszystkie robotnice ze słabą pobudliwością, mimo iż wśród usuwanych $\mathrm{z}$ tego wydziału dużo było pracownic inteligentnych, pracowitych i sumiennych. Dla ich dobra zostały przeniesione do innych zajęć, także do dwustopniowej sekcji kontrolnej nad pracą sortowaczek, gdzie na równi ceniona była sumienność pracownicza. Taylor mógł ogłosić sukces: wskutek reorganizacji pod dyktando przeprowadzonych badań personel zredukowany został ze 120 do 35 kontrolerek, skrócono czas ich pracy z 10,45 do 8,5 godz., wprowadzono w odstępach 2,15 godz. obligatoryjne przerwy rekreacyjne z zakazem siedzenia na stanowisku roboczym; wskazany był ruch i rozmowy, gdyż podczas okresów pracy konwersacja była zabroniona. Wszystkie robotnice miały prawo do 2 dni płatnych w miesiącu, wybieranych $\mathrm{w}$ dowolnej chwili. Ich zarobki podniosły się w przedziale $80-100 \%$, zaś przedsiębiorca zyskał na podniesieniu jakości produktu, zmniejszeniu kosztów wytwórczych w zakresie kontroli mimo zwiększonych płac i wydatków związanych z nowymi stanowiskami kontrolnymi, jak też poprawienie stosunków pomiędzy zarządem a załogą (Taylor, 1922, s. 55). Problem negatywnej społecznej recepcji tkwił w tym, iż nie wszystkie uzunięte pracownice znalazły - dzięki wskazaniom psychotechniki - nowe bardziej odpowiadające im zajęcie w tym średniej wielkości przedsiębiorstwie. Zaś metody psychotechniki nie trafiłyby do przemysłu, gdyby nie dążenia kapitalistów/ właścicieli do osiągania coraz wyższych przychodów. Osobnego, by tak rzec, „funduszu psychotechnicznego" pozwalającego realizować, jak chciał Zawirski, szczytne zamierzenia $\mathrm{w}$ środowisku pracy zawodowej, przecież nie było.

Badania nad uzdolnieniem do zawodów trudnych bądź zagrażających życiu szczególnie mocno rozwinęły się w Niemczech. Za ich początek uznaje się rozpoczęte w 1916 roku przez Walthera Moede (1888-1958) i Curta Piorkowskiego (1888-1939) badanie zdatności szoferów w pojazdach mechanicznych za pomocą aparatu nazwanego ich imieniem, w którym akcent położony był na koordynację wzrokowo-ruchową. Inspiracją tych badań były potrzeby wojenne, ale wkrótce stały się tak popularne, iż objęły maszynistów kolei żelaznych, motorniczych $\mathrm{w}$ tramwajach oraz wkroczyły do przemysłu fabrycznego. Próby te przyniosły pozytywne wyniki, czego efektem stała się praktyka, iż nie było w Niemczech większej organizacji gospodarczej niezatrudniającej psychologa. Więcej o sytuacji w Niemczech i krajach niemieckojęzycznych można było przeczytać w publikacjach pochodzącej z Łodzi dr Franciszki Baumgarten, późniejszej profesor Uniwersytetu w Bernie i znanej psycholog (Baumgarten, 1922). 
Aspiracją psychotechniki stało się również badanie uzdolnień do wykonywania zawodów wyższych, jak architekt, redaktor, literat, badacz przyrody, lekarz czy menedżer wielkiej firmy, jakkolwiek panowało przekonanie, iż sprawa tu jest „o wiele trudniejsza niż przy badaniu uzdolnień pracowników fizycznych” (Zawirski, 1926, s. 152). Zagadnieniu temu poświęcone były kongresy psychologii eksperymentalnej, jak też jej zastosowań, o czym informowały na swych łamach „Ruch Filozoficzny”, a także „Przegląd Pedagogiczny”. Dla ilustracji tych dążeń Zawirski posłużył się fragmentem badań Theodora Erismanna (1883-1961) zawierającym tabelaryczną propozycję zawartości właściwości i predyspozycji tak fizycznych bądź ich braku (np. chorób), jak sprawności zmysłowych, pamięci, wyobraźni, woli, uwagi, myślenia czy zdolności specjalnych (np. zmysł porządku, cierpliwość, skłonności techniczne) dla kandydatów do dziewięciu zawodów: motorniczego, tokarza, kupca, zecera, piszącego na maszynie, telefonistki, rolnika, hodowcy bydła i dentysty (Th. Erismann, M. Moers: Psychologie der Berufsarbeit und Berufsberatung (Psychotechnik), Sammlung Göschen, Berlin 1922). Operowanie tabelą było proste. Jeśli jakaś własność była niezbędna, oznaczono ją kółkiem największym, jeśli pożądana - średnim, jeśli nieistotna - najmniejszym. W następstwie tego i wielu innych propozycji będących wynikiem eksperymentalnych badań nad uwarunkowaniami człowieka w miejscu pracy stała się fala zakładania poradni zawodowych i przesądzania o losie młodych osób już w wieku szkolnym. „Poradnie zawodowe badały wszechstronnie uzdolnienie dziecka, aby w ten sposób można było skierować każdą jednostkę do zawodu odpowiadającego jego zdolnościom i uchronić ją od wyboru zawodu nieodpowiedniego" (Zawirski, 1926, s. 152).

Swój wywód na temat psychotechniki Zawirski zakończył podniesieniem kilku kwestii teoretycznych, związanych z jej uprawianiem i dalszym rozwojem ${ }^{7}$. Do pierwszej zaliczył sprawę samych metod, stwierdzających posiadanie zdolności potrzebnych do wykonywania danej pracy, jak też zbadanie, czy dany osobnik je posiada. Czy badania prowadzić w oparciu o testy czy za pomocą aparatury? A tych ostatnich namnożyło się całe mnóstwo, ściśle na użytek psychotechniki i niekiedy nie posiadały umocowania w psychologii ogólnej. Związaną z tym dalszą ważną kwestią była sprawa stosunku zdolności nabytych do wrodzonych ze względu na ich rolę w pracy zawodowej. Przecież dzięki nabywaniu wprawy, zdolności mogą ulegać zmianie. Psychotechnika nie zadowala się tylko eliminacją jednostek pozbawionych uzdolnień, jak to działo się w latach wielkiej wojny, ale rozpoczęła swój rozwój w stronę doboru pozytywnego. Powinna wskazywać poszczególnym kandydatom kierunki dalszych ćwiczeń, by nadrobić brak na przykład jednej ważnej zdolności przy posiadaniu zestawu innych niezbędnych dla danego zawodu. Kolejną kluczową kwestią okazał się stosunek cech moralnych danego osobnika do wydajności pracy. Nawet kompletny zestaw zdolności do wykonywania zawodu nie stanowi gwarancji osiągania zadanego poziomu wydajności u kogoś obciążonego wadami charakteru moralnego. Podobnie, jak szukanie odpowiedzi, czy zamiłowanie do danego zawodu świadczy zarazem o posiadaniu niezbędnych zdolności do jego uprawiania. Odpowiedzi na te kwestie nie są łatwe, ale powstałe na ich tle wątpliwości nie mogły przekreślać korzyści, jakie psychotechnika już przyniosła.

\section{Podsumowanie}

W opracowaniu odtworzone zostały zainteresowania Zawirskiego psychologią o charakterze eksperymentalnym, stanowiącą podstawę do rozwoju jej zastosowań. Jednym z kierunków była psychotechnika znajdująca swoje aplikacje $\mathrm{w}$ przemyśle, tak poprzez zakładanie placówek poradnictwa, jak też inicjowanie i prowadzenie prac badawczych w zakresie psychofizjologicznych możliwości pracowniczych. Zawirski, może bardziej niż inni jej zwolennicy, kładł akcent na mocne zakotwiczenie prac psychotechnicznych w podstawach teoretycznych psychologii. Sam był filozofem nauki, szczególnie przyrodoznawstwa; psychologia - wyłącznie eksperymentalna, bo jedynie wtedy naukowa - mogła być zwieńczeniem od strony humanistycznej tychże nauk. Jej psychotechniczne stosowania $\mathrm{w}$ obszarze organizacji przemysłu i przedsiębiorstwa $\mathrm{z}$ pewnością ułatwiały zarządzanie w odsłonie personalnej tymi jednostkami. Była tym samym jedną z zapowiedzi zarządzania zasobami ludzkimi. Generalnie o tej prekursorskiej roli psychotechniki wiadomo. Obecność w niej Zygmunta Zawirskiego uchodziła dotąd uwadze. A było jeszcze bezpośrednie uczestnictwo w tworzeniu pracowni, który to wkład będzie podjęty w następnej sekwencji tegoż przypomnienia.

\section{dr hab. Alojzy Czech, prof. uczelni Uniwersytet Ekonomiczny w Katowicach ORCID: 0000-0002-3468-5859 \\ e-mail: aczech@ue.katowice.pl}

\section{Przypisy}

1) Były to: artykuł o ilości praw kojarzenia z 1909 roku oraz dwa tłumaczenia: podręcznik filozofa A. Höflera polecony do przełożenia prawdopodobnie przez K. Twardowskiego oraz artykuł L.. Walthera o psychologii pracy, o czym więcej w treści.

2) $\mathrm{W}$ podręcznikowej wersji brzmi ono: „Szeregowi geometrycznie rosnących wielkości podniet zmysłowych towarzyszy szereg arytmetycznie rosnących natężeń wrażeń" (J. Pieter, 1976, s. 125). Akcentuje się również znaczny udział G. Fechnera w jego sformułowaniu.

3) M.in. zob. tegoż: Znużenie w szkole. Na podstawie pomiarów aisthesiometrem sprężynowym. Przyczynek do doświadczalnej psychologii, skład Księgarni H. Altenberga, Lwów 1899 (więcej zob. Błażek Bolesław, [w:] Słownik psychologów polskich, 1992, s. 34; autor: A. Mężyk). 
4) Wydany został także obszerny wybór prac H. Münsterberga, Grundzüge der Psychotechnik (J.A. Barth, Leipzig 1915; 2. wyd. 1920) często przywoływany przez wielu autorów.

5) Franziska Baumgarten (1883-1970) była jedną z nielicznej grupy słuchaczy Münsterberga relacjonującego w cyklu wykładów swoje amerykańskie dokonania w 1911 roku w Berlinie. Nie wzbudziły one wtedy większego zainteresowania (Baumgarten, 1930, s. 17).

6) Zawirski nie korzystał z Fr. Taylora Shop Management (Harper \& Bross, New York 1903, polskie wydanie Zarzadzanie warsztatem wytwórczym, tł. I. Szumlakowska, Instytut Naukowej Organizacji, Warszawa 1926), zaś znana mu edycja polska Principles of scientific management/Zasady organizacji naukowej zakładów przemysłowych w tł. H. Mierzejewskiego była 3. wydaniem polskim (Wydawnictwo „Ligi Pracy”, Warszawa 1923).

7) Jak się wydaje, Zawirski w tym miejscu powoływał się na rozważania E. Claparéde: Poradnictwo zawodowe. Zadania i metody. Tł. M. Sokalowa, Wydawnictwo „Ligi Pracy”, Warszawa 1924.

\section{Bibliografia}

[1] Archiwum UAM w Poznaniu, sygn. 152/32.

[2] Archiwum Uniwersytetu Jagiellońskiego, sygn. S/II/619.

[3] Barylski A. (2013), Profesor Edward T. Geisler, „Pismo Politechniki Gdańskiej", Nr 7, s. 51-55.

[4] Baumgarten F. (1922), Psychotechnika gospodarcza, „Ruch Filozoficzny", t. VII, Nr 1-2-3, s. 1-9.

[5] Baumgarten F. (1930), Badania uzdolnień zawodowych, przeł. J. Saloni, „Książnica - Atlas”, Lwów-Warszawa.

[6] Bocheński J. (1993), Wspomnienia, Philed, Kraków.

[7] Galeński W. (1948), Zygmunt Zawirski wspomnienie pośmiertne, „Życie Nauki”, t. VI, nr 31-32, lipiec-sierpień.

[8] Gawecki B.J. (1948), Zygmunt Zawirski (1882-1948), „Przegląd Filozoficzny", r. 44, z. 4, s. 436-443.

[9] Geisler E.T. (1926), Psychotechnika, jej cele i drogi, „Czasopismo Techniczne", r. 44, Nr 10 , s. 154-162.

[10] Hajduk Z. (2011), Zawirski Zygmunt Michał, [w:] Encyklopedia Filozofii Polskiej, t. 2, Polskie Towarzystwo Tomasza z Akwinu, Lublin.

[11] Ingarden R. (1948), Wspomnienie o prof. Zawirskim, „Dziennik Literacki” dodatek do „Dziennika Polskiego", Kraków, R. 1948/2, Nr 18, s. 7.

[12] Jadacki J.J. (1998), Orientacje i doktryny filozoficzne: $z$ dziejów myśli polskiej, Wydział Filozofii i Socjologii UW, Warszawa.

[13] Jadczak R. (1993), Lwowski i poznański okres w działalności naukowej Zygmunta Zawirskiego, „Edukacja Filozoficzna”, Vol. 16, s. 197-205.

[14] Martyniak Z. (1993), Prekursorzy nauki organizacji i zarządzania, Wyd. 2, PWE, Warszawa.

[15] Pieter J. (1976), Historia psychologii, Wyd. 3, PWN, Warszawa.

[16] Politechnika Lwowska, jej stan obecny i potrzeby (1932), staraniem Grona Profesorów, Lwów.

[17] Rzepa T., Dobraczyński B. (2009), Historia polskiej myśli psychologicznej, Wydawnictwo Naukowe PWN, Warszawa.

[18] Słownik psychologów polskich (1992), pod red. E. Kosnarewicz, T. Rzepy i R. Stachowskiego, Wydawnictwo UAM, Poznań.
[19] Szumilewicz-Lachman I. (1994), Zygmunt Zawirski, His Life and Work, Kluwer Academic Publ., Dordrecht-Boston-London.

[20] Taylor F. (1922) Zasady organizacji naukowej zakładów przemysłowych, 2 wyd., Wydawnictwo „Ligi Pracy”, Warszawa.

[21] Woleński J. (1985), Filozoficzna szkoła lwowsko-warszawska, PWN, Warszawa.

[22] Zamecki S. (1977), Koncepcja nauki w szkole lwowsko-warszawskiej, Ossolineum, Wrocław-Warszawa-Kraków-Gdańsk.

[23] Zawirski Z. (1909), Ilość praw kojarzenia przedstawień, [w:] „Sprawozdanie Dyrekcji C.K. II Gimnazjum w Rzeszowie za rok szkolny 1909”, Rzeszów.

[24] Zawirski Z. (1926), Podstawy psychotechniki i jej rozwój, „Czasopismo Techniczne”, R. 44, Nr 10, s. 149-154.

\section{Zygmunt Zawirski among Engineers and Organisers: Part 1}

\section{Summary}

Professor of universities in Poznan and Cracow, one of the most meaningful philosophers of science in Poland in the time between the world wars. He was dealing with contemporary logic and its applications and methodology of natural science; also, he was the author of historical essays in philosophy. However, even in such a busy life of his, devoted to scientific works and teaching, he marked short though very close co-operation with technological and organisational circles. The subject matter of this co-operation was application of psychology in professional work in the industry. Professor Zawirski wrote an article, not very popular today, addressed to the world of technologists and engineers, touching on psychotechnicians' efforts representing various concepts of empirical psychology.

This article appeared fruitful: professor Zawirski was entrusted with the function of the organiser and head of the psychotechnical laboratory for young artisans and given a mission to carry out vocational advice service. That history happened in Lviv, between 1926 and 1928. He was speaking about these achievements at the $2^{\text {nd }}$ Polish Congress of Scientific Management in Warsaw in 1928. The co-operation with the organisational circles was interrupted as a result of appointing Zawirski a Head of the Theory and Methodology of Science Chair at the University of Poznań. Nevertheless, his continued interest in practical psychology expressed itself in his translations of French literature on this matter. The paper describes scientific personality of professor Zawirski, a philosopher of science, logician and methodologist with the forgotten episode of his connections with psychology and psychotechnics presented among engineers.

\section{Keywords}

history of management, Zygmunt Zawirski, philosophy of science, psychotechnics, vocational advisory 